\title{
Synthesis of the BCAC4ND2 Ionophore from p-t-Butylcalix[4]arene Ethylester
}

\author{
Nasriadi, $D^{1 *}$, Arniah, $D^{2}$, and Seniwati, $D^{3}$ \\ ${ }^{1}$ Department of Chemistry, Faculty of Mathematics and Natural Sciences, University of Halu Oleo, \\ Kendari 93232 - Southeast Sulawesi, Indonesia \\ ${ }^{2}$ Department of Chemistry Education, Faculty of Teacher Training and Education, University of \\ Halu Oleo, Kendari 93232 - Southeast Sulawesi, Indonesia \\ ${ }^{3}$ Department of Chemistry, Faculty of Mathematics and Natural Sciences, Hasanuddin University, \\ Makassar 90245 - South Sulawesi, Indonesia \\ *Corresponding author: nasriadidali@ymail.com
}

\begin{abstract}
Research on the synthesis of the BCAC4ND2 ionophore from p-t-butylcalix[4]arene ethylester has been carried out. This study aims to synthesize the BCAC4ND2 ionophor from p-t-butylcalix[4]arene ethylester. The BCAC4ND2 ionophore is synthesized by hydrolyzing p-t-butylcalix[4]arene ethylester in aqueous $\mathrm{KOH}$-ethanol of $95 \%$. The hydrolysis reaction of these base-promoted esters are refluxed for 28 hours at 78 ${ }^{\circ} \mathrm{C}$. The BCAC4ND2 ionophore was identified and characterized by melting point, thin layer chromatography (TLC), FTIR, ${ }^{1} H-N M R$, and ${ }^{13} C$-NMR spectrometers. The BCAC4ND2 ionophore obtained was in the form of white solid (62.38\% recovery), a melting point $326-328{ }^{\circ} \mathrm{C}$, and $\mathrm{TLC}\left(\mathrm{SiO}_{2}\right.$, ethanol : ethylacetate $=1: 1 \mathrm{v} / \mathrm{v}, R_{f}=0.93$ ).
\end{abstract}

Keywords: synthesis, BCAC4ND2 ionophore, calix[4]arene, hydrolysis, esters, carboxylic acid

\begin{abstract}
Abstrak
Penelitian tentang sintesis ionofor BCAC4ND2 dari p-t-butilkaliks[4]arena etilester telah dilakukan. Penelitian ini bertujuan untuk mensintesis ionofor BCAC4ND2 dari p-t-butilkaliks[4]arena etilester. Ionofor BCAC4ND2 disintesis dengan cara menghidrolisis p-t-butilkaliks[4]arena etilester dalam larutan KOH-etanol 95\%. Reaksi hidrolisis ester terpromosi basa ini direfluks selama 28 jam pada suhu $78{ }^{\circ} \mathrm{C}$. Ionofor BCAC4ND2 diidentifikasi dan dikarakterisasi dengan titik leleh, kromatografi lapis tipis (KLT), spektrometer FTIR, ${ }^{1} \mathrm{H}$-NMR, dan ${ }^{13} \mathrm{C}$-NMR. Ionofor BCAC4ND2 yang diperoleh berupa padatan putih (perolehan 62,38\%), titik leleh 326-328 ${ }^{\circ} \mathrm{C}$, dan $\mathrm{KLT}\left(\mathrm{SiO}_{2}\right.$, etanol $:$ etilasetat $\left.=1: 1 \mathrm{v} / \mathrm{v}, R_{f}=0,93\right)$.
\end{abstract}

Kata Kunci: sintesis, ionofor BCAC4ND2, kaliks[4]arena, hidrolisis, ester, asam karboksilat 


\section{Introduction}

Calixarene is included in the group of macrocyclic molecules. Calixarene is composed of aromatic units connected by a methylene bridge. Calixarene can be synthesized and modified widely, so that we can produce different types and quantities of aromatic units, methylene bridges, and different functional groups [1].

Calixarene is a vase-shaped flower that has a variety of cavity diameters. This geometric shape causes calixarene can be used in the host-guest system, where calixarene acts as a host and ions or other molecules act as guest [1]. The ability of calixarene in forming host-guest interactions makes the use of calixarene in chemistry more extensive.

Calixarene can be used as an ionophore because it has a cavity and two functional groups, namely the functional groups above and below the annulus ring. Both of these functional groups can be modified to produce ionophores that are selective about compounds or metal ions [2] [3] [4]. For example, modification of the $t$-butyl group over the annular ring with a tetramer or hexamer group produces an ionophore that is selective to the cations of $\mathrm{Rb}, \mathrm{Sr}, \mathrm{Cs}$, alkali metals, and alkaline earth metals [5]. Modification of hydroxyl groups under the annulus ring with carboxylic, sulfonato, alkenyl, and DOI: http://dx.doi.org/10.12962/j25493736.v5i1.6711 haloalkyl groups produces ionophores that are selective to the cations of $\mathrm{Fe}^{3+}, \mathrm{Ni}^{2+}$, $\mathrm{Pb}^{2+}$, and $\mathrm{Cr}^{3+}$ [6] [7] [8].

One of the derivative compounds of calix[4]arenes that can be modified into ionophores is the $p$-t-butylcalix[4]arene ethylester compound. Ionofor BCAC4ND2 can be synthesized by hydrolyzing $p$ - $t$ butylcalix[4]arene ethylester in $96 \%$ $\mathrm{KOH}$-ethanol solution [9]. In the hydrolysis reaction of this base-promoted ester, the ethylester group under the annulus ring in the $p$-t-butylcalix[4]arene compound is converted to a carboxylic group.

\section{Experiment}

\section{Tools and Materials}

A set of reflux devices consisting of $100 \mathrm{~mL}$ three-neck round bottom flask, ball coolers, thermometers $\left(100{ }^{\circ} \mathrm{C}\right), 1 \mathrm{~cm}$ magnetic stirrers, heating mantles, and funnels. Spectrometers used included the FTIR Prestige-21 Shimadzu and FTNMR JEOL ECX500. Other supporting tools are desiccator, analytical balance (Explorer Ohaus), Electrothermal 9100, dropper pipette (Pyrex), measuring cup (Pyrex), chemical beaker (Pyrex), stirring rod, and chamber.

The raw material, $p$-tbutylcalix[4]arene ethylester (synthesized) [8], potassium hydroxide (Merck), ethanol (Merck), hydrochloric acid (Merck), chloroform (Merck), distilled water, and 
TLC plate. All solvents were obtained from commercial sources and used without further treatment.

\section{Synthesis of the BCAC4ND2 Ionophore}

The raw material $(2.0 \mathrm{~g}, 0.0027 \mathrm{~mol})$ is put into a $100 \mathrm{~mL}$ three-neck round bottom flask equipped with a ball cooler. Furthermore, a solution of $\mathrm{KOH}(0.5 \mathrm{~g}$, $0.0089 \mathrm{~mol}$ ) in $100 \mathrm{~mL}$ ethanol of $95 \%$ was added to the three-neck round bottom flask. The solution was refluxed for 28 hours at $78{ }^{\circ} \mathrm{C}$ and every 8 hours the solution was tested TLC. After cooling, the solution is acidified with $1 \mathrm{M} \mathrm{HCl}$. The precipitate formed was filtered and then washed with $2 \times 2.5 \mathrm{~mL}$ of $1 \mathrm{M} \mathrm{HCl}$ solution and $3 \times 2.5 \mathrm{~mL}$ of water. The solids formed are dried in a desiccator, then recrystallized with ethanol to form a white powder (BCAC4ND2 ionophore). Furthermore the BCAC4ND2 ionophore was dried in a desiccator and then characterized by TLC, melting point, FTIR, ${ }^{1} \mathrm{H}-\mathrm{NMR}, \quad$ and ${ }^{13} \mathrm{C}-\mathrm{NMR}$ spectrometers [10].

Determination of the BCAC4ND2 Ionophore Structure

The BCAC4ND2 ionophore structure was determined using spectroscopic techniques, namely FTIR and FTNMR 1-D $\left({ }^{1} \mathrm{H}\right.$ and $\left.{ }^{13} \mathrm{C}\right)$. The physical data and spectrum of FTIR, ${ }^{1} \mathrm{H}$ and ${ }^{13} \mathrm{C}-\mathrm{NMR}$ of the BCAC4ND2 ionophore are as follows. Yield: $1.2476 \mathrm{~g}$ $(62.38 \%)$; mp $326-328{ }^{\circ} \mathrm{C}$; TLC $\left(\mathrm{SiO}_{2}\right.$, ethanol : ethyl acetate $=1: 1 \mathrm{v} / \mathrm{v}, \mathrm{R}_{\mathrm{f}}=$ 0.93). FTIR spectrum $(\mathrm{KBr}) v_{\max }\left(\mathrm{cm}^{-1}\right)$ : 3450,65 (OH acid), 1739,79 ( $\mathrm{C}=\mathrm{O}$ acid), 1244,09 (COC alkyl aryl ether), 1089,78 (RCO alkyl aryl ether), 1637,56 (C=C aromatic), 1201,65 (C-O aromatic), 817,82 and 711,73 (CH OOP aromatic), 2956,87, 2920,23, and 2850,79 (CH saturated aliphatic), 1455,09 ( $\mathrm{CH}_{3}$ aliphatic), 1465,9 $\left(\mathrm{CH}_{2}\right.$ aliphatic). ${ }^{1} \mathrm{H}-\mathrm{NMR}$ spectrum (500 $\left.\mathrm{MHz}, \mathrm{CDCl}_{3}\right) \delta_{\mathrm{H}}(\mathrm{ppm}): 10,3353[(\mathrm{~s}, 1 \mathbf{H})$ $\left.\left(\mathrm{OH}-1^{*}\right)\right], 7,0484$ [(s, 1H) (ArH-22/24)], 4,4776 [(s, 2H) $\left(\mathrm{CH}_{2} \mathrm{O}-2\right.$ ") $), 4,2474$ [(d, $2 \mathbf{H}, J=12,9 \mathrm{~Hz})\left(\operatorname{ArCH}_{2} \operatorname{Ar}-20\right.$, endo)], 3,3939 [(d, 2H, $J=12,9 \mathrm{~Hz})\left(\mathrm{ArCH}_{\mathbf{2}} \mathrm{Ar}-2\right.$, ekso $)], 1,2556\left[(\mathrm{~s}, 9 \mathbf{H})\left(\mathrm{C}\left(\mathrm{CH}_{3}\right)_{3}-2\right.\right.$ ') $] .{ }^{13} \mathrm{C}-$ NMR spectrum $\left(500 \mathrm{MHz}, \mathrm{CDCl}_{3}\right) \delta_{\mathrm{C}}$ $(\mathrm{ppm}): \quad 170,3153 \quad\left[\left(\mathbf{C O}_{2} \mathrm{H}\right) \quad(\mathbf{C}-1 ”)\right]$, 146,8503 [(CO aryl) (C-25)], 144,5516 [(C-para aryl) (C-23)], 127,8691 [(Cortho aryl) (C-1/C-21)], 126,1236 [(Cmeta aryl) (C-22/C-24)], 73,1351 $\left[\left(\mathrm{OCH}_{2} \mathrm{CO}_{2} \mathrm{H}\right) \quad(\mathrm{C}-2 ”)\right], \quad 34,1932$ $\left[\left(\mathbf{C}\left(\mathrm{CH}_{3}\right)_{3}\right) \quad\left(\mathbf{C}-1^{\prime}\right)\right], \quad 31,5892 \quad\left[\left(\mathrm{C}^{\prime} \mathbf{C H}_{3}\right)_{3}\right)$ $\left.\left(\mathbf{C}-2^{\prime}\right)\right]$, and 30,2348 [( $\left.\mathrm{ArCH}_{2} \mathrm{Ar}\right)(\mathbf{C}-2 / \mathbf{C}-$ 20)].

\section{Results and Discussion}

The ionophore BCAC4ND2 was obtained by hydrolyzing $p$ - $t$ butylcalix[4]arene ethylester in aqueous 
$\mathrm{KOH}-$ ethanol of $95 \%$ (Figure 1) [9]. The

BCAC4ND2 ionophore was obtained as a white solid substance (62.38\% recovery), a melting point of $326-328{ }^{\circ} \mathrm{C}$, and $\mathrm{R}_{\mathrm{f}} 0,93$ on TLC $\left(\mathrm{SiO}_{2}\right.$, ethanol : ethylacetate $=1$ :
$1 \mathrm{v} / \mathrm{v})$. The melting point of the BCAC4ND2 ionophore is in accordance with the melting point of compounds obtained by Kadir [6] and Maming [11].



Figure 1. Synthesis of the BCAC4ND2 ionophore from $p$-t $t$-butylcalix[4]arene ethylester

In the base-promoted ester absorption band at $671.23 \mathrm{~cm}^{-1}$ from hydrolysis reaction above (Figure 1) it appears that the ethyl ester group ($\left.\mathrm{CO}_{2} \mathrm{CH}_{2} \mathrm{CH}_{3}\right)$ in $p$-t-butylcalix[4]arene ethylester is converted to a carboxylic group $\left(-\mathrm{CO}_{2} \mathrm{H}\right)$ on the BCAC4ND2 ionophore. The success of the basepromoted ester hydrolysis reaction is supported by FTIR spectra data of synthesis products (BCAC4ND2 ionophore). From FTIR spectrum data (Table 1) it appears that the BCAC4ND2 ionophore does not show a strong and sharp absorption band at $1743.65 \mathrm{~cm}^{-1}$ of bending $\mathrm{O}-\mathrm{C}-\mathrm{O}$ ester. According to Lambert [13] strong absorption bands in the range of $675-575 \mathrm{~cm}^{-1}$ are typical for bending $\mathrm{O}-\mathrm{C}-\mathrm{O}$ esters. The presence of wide and strong absorption bands at $3450.65 \mathrm{~cm}^{-1}$ and strong absorption bands at $1739.79 \mathrm{~cm}^{-1}$ indicates that the BCAC4ND2 ionophore contains hydrogen-bonded $\mathrm{O}-\mathrm{H}$ groups and carbonyl groups $(\mathrm{C}=\mathrm{O})$ of carboxylic acids. These four FTIR spectrum data indicate that the reaction of the basepromoted ester hydrolysis has taken place. the carbonyl group $(\mathrm{C}=\mathrm{O})$ ester and strong 
Table 1. The FTIR spectrum of the $p$-t-butylcalix[4]arene ethylester (raw material) and the BCAC4ND2 ionophore

\begin{tabular}{|c|c|c|c|c|c|}
\hline \multirow[b]{2}{*}{ No } & \multicolumn{2}{|c|}{ Frequency $\left(\mathrm{cm}^{-1}\right)$ and Intensities } & \multirow{2}{*}{$\begin{array}{c}\text { Frequency Ranges } \\
\qquad\left(\mathrm{cm}^{-1}\right) \text { and } \\
\text { Intensities* }\end{array}$} & \multirow[b]{2}{*}{ Group or Class } & \multirow[b]{2}{*}{ Remarks } \\
\hline & Raw Material & $\begin{array}{l}\text { BCAC4ND2Io } \\
\text { nophore }\end{array}$ & & & \\
\hline 1 & - & 3450,65 (vs) & $3400-2400(\mathrm{~s})$ & \multirow[b]{2}{*}{$\begin{array}{l}\text { Carboxylic Acids } \\
\text { RCOOH }\end{array}$} & $\mathrm{OH}$ stretch \\
\hline 2 & - & 1739,79 (vs) & $1730-1700$ (vs) & & $\mathrm{C}=\mathrm{O}$ stretch \\
\hline 3 & $1743,65(\mathrm{vs})$ & - & $1765-1720(v s)$ & Esters & $\mathrm{C}=\mathrm{O}$ stretch \\
\hline 4 & $671,23(\mathrm{~s})$ & - & $675-575(s)$ & RCOOR' & O-C-O bend \\
\hline 5 & $1244,09(\mathrm{~s})$ & $1244,09(\mathrm{~s})$ & $1280-1220(\mathrm{~s})$ & $\begin{array}{l}\text { Ethers } \\
\text { ROR' }\end{array}$ & $\begin{array}{l}\text { C-O-C stretch in alkyl aryl } \\
\text { ethers }\end{array}$ \\
\hline 6 & 1066,64 (m) & $1089,78(\mathrm{~s})$ & $1075-1020(\mathrm{~s})$ & & $\begin{array}{l}\text { R-C-O stretch in alkyl aryl } \\
\text { ethers }\end{array}$ \\
\hline 7 & 1604,77 (vs) & $1637,56(s)$ & $1630-1430(v)$ & Aromatic & $\begin{array}{l}\mathrm{C}=\mathrm{C} \text { aromatic ring } \\
\text { stretching }\end{array}$ \\
\hline 8 & 1201,65 (vs) & 1201,65 (vs) & $1300-1000(\mathrm{~s})$ & & $\begin{array}{l}\mathrm{C}-\mathrm{O} \text { aromatic ring } \\
\text { stretching }\end{array}$ \\
\hline 9 & $877,61(w)$ & $817,82(w)$ & $900-650(\mathrm{~s})$ & & Out-of-plane C-H \\
\hline 10 & $846,75(\mathrm{~s})$ & $711,73(w)$ & & & disubstituted \\
\hline 11 & $2958,8(w)$ & 2956,87 (w) & $2970-2850(\mathrm{~s})$ & Aliphatic & $\mathrm{C}-\mathrm{H}$ stretch from saturated \\
\hline 12 & 2924,09 (w) & 2920,23 (vs) & & RH & $\left(\mathrm{CH}_{3}\right)_{3} \mathrm{C}-$ \\
\hline 13 & $2854,65(w)$ & $2850,79(\mathrm{~s})$ & & & \\
\hline 14 & $1435,04(\mathrm{~s})$ & $1455,09(\mathrm{~m})$ & $1450-1375(\mathrm{~s})$ & $\begin{array}{c}t \text {-Butyl } \\
\left(\mathrm{CH}_{3}\right)_{3} \mathrm{C}-\end{array}$ & $\mathrm{C}-\mathrm{H}$ stretch from $\mathrm{CH}_{3^{-}}$ \\
\hline 15 & $1485,19(w)$ & $1465,9(\mathrm{~m})$ & $1485-1450(\mathrm{~m})$ & $\begin{array}{l}\text { Methylene } \\
-\mathrm{CH}_{2^{-}}\end{array}$ & $\mathrm{C}-\mathrm{H}$ stretch from $-\mathrm{CH}_{2^{-}}$ \\
\hline
\end{tabular}

-Notes: vs = very strong $; \mathrm{v}=$ variable $; \mathrm{s}=$ strong $; \mathrm{m}=$ medium $; \mathrm{w}=$ weak.

*Sources: [12] [13] [14]

The success of the base-promoted ester hydrolysis reaction is also supported by the BCAC4ND2 ionophore ${ }^{1} \mathrm{H}-\mathrm{NMR}$ spectrum data. From the ${ }^{1} \mathrm{H}-\mathrm{NMR}$ spectrum data (Table 2) it appears that the
BCAC4ND2 ionophore does not show any signal at $\delta_{\mathrm{H}} 4.2045 \mathrm{ppm}(2 \mathbf{H}, q, J=6.7$ $\mathrm{Hz}$ ) of the methylene ethoxy proton $\left(\mathrm{OCH}_{2} \mathrm{CH}_{3}-1 *\right)$ next to the neighboring methyl ethoxy proton $\left(\mathrm{OCH}_{2} \mathrm{CH}_{3}-2^{*}\right)$ 
which appears at $\delta_{\mathrm{H}} 4,2045 \mathrm{ppm}(2 \mathbf{H}, q, J$ $=6.7 \mathrm{~Hz}$ ). The presence of a signal at $\delta_{\mathrm{H}}$ $10.3353 \mathrm{ppm}(1 \mathbf{H}, s)$ indicates that the BCAC4ND2 ionophore contains carboxylic acid proton (OH-1*). According to Kemp [14] OH carboxylic acid protons in the ${ }^{1} \mathrm{H}-\mathrm{NMR}$ spectrum appear at $\delta_{\mathrm{H}} 10-13 \mathrm{ppm}$.

Table 2. The NMR $\left({ }^{1} \mathrm{H},{ }^{13} \mathrm{C}\right)$ spectrum of the $p$ - $t$-butylcalix[4]arene ethylester (raw material) and the BCAC4ND2 ionophore

\begin{tabular}{|c|c|c|c|c|c|c|c|}
\hline \multirow{2}{*}{$\begin{array}{c}\mathrm{C} \\
\text { Position }\end{array}$} & \multicolumn{2}{|c|}{$\delta_{\mathrm{C}}(\mathrm{ppm})$} & \multirow[b]{2}{*}{ Groups } & \multirow{2}{*}{$\begin{array}{c}\mathrm{H} \\
\text { Position }\end{array}$} & \multicolumn{2}{|c|}{$\delta_{\mathrm{H}}(\mathrm{ppm})$} & \multirow[b]{2}{*}{ Groups } \\
\hline & $\begin{array}{c}\text { Raw } \\
\text { Material }\end{array}$ & $\begin{array}{c}\text { BCAC4ND2 } \\
\text { Ionophore }\end{array}$ & & & $\begin{array}{c}\text { Raw } \\
\text { Material }\end{array}$ & $\begin{array}{c}\text { BCAC4ND2 } \\
\text { Ionophore }\end{array}$ & \\
\hline 1,21 & 132,9455 & 127,8691 & C- $o$ aryl & & - & - & - \\
\hline 22,24 & 125,5032 & 126,1236 & C- $m$ aryl & 22,24 & $\begin{array}{l}6,5283 \\
(1 \mathbf{H}, s)\end{array}$ & $\begin{array}{r}7,0484 \\
(1 \mathbf{H}, s)\end{array}$ & $\operatorname{Ar} \mathbf{H}$ \\
\hline 23 & 146,6711 & 144,5516 & C- $p$ aryl & & - & - & - \\
\hline 25 & 153,1262 & 146,8503 & CO aryl & & - & - & - \\
\hline 1 ' & 34,3669 & 34,1932 & $\mathrm{C}\left(\mathrm{CH}_{3}\right)_{3}$ & & - & - & - \\
\hline $2^{\prime}$ & 31,4291 & 31,5892 & $\mathrm{C}\left(\mathrm{CH}_{3}\right)_{3}$ & $2^{\prime}$ & $\begin{array}{l}1,0467 \\
(9 \mathbf{H}, s)\end{array}$ & $\begin{array}{l}1,2556 \\
(9 \mathbf{H}, s)\end{array}$ & $\mathrm{C}\left(\mathrm{CH}_{3}\right)_{3}$ \\
\hline 20 & 31,7629 & 30,2348 & $\mathrm{ArCH}_{2} \mathrm{Ar}$ & 2 & $\begin{array}{c}4,8548 \\
(2 \mathbf{H}, d, J= \\
12,9 \mathrm{~Hz})\end{array}$ & $\begin{array}{c}4,2474 \\
(2 \mathbf{H}, d, J= \\
12,9 \mathrm{~Hz})\end{array}$ & $\begin{array}{c}\mathrm{ArCH} \mathbf{H}_{2} \mathrm{Ar} \\
\text { endo }\end{array}$ \\
\hline 2 & & & & & $\begin{array}{c}3,1925 \\
(2 \mathbf{H}, d, J= \\
12,9 \mathrm{~Hz})\end{array}$ & $\begin{array}{c}3,3939 \\
(2 \mathbf{H}, d, J= \\
12,9 \mathrm{~Hz})\end{array}$ & $\begin{array}{c}\mathrm{ArCH} \mathbf{H}_{2} \mathrm{Ar} \\
e k s o\end{array}$ \\
\hline & 169,6680 & - & $\mathbf{C}=\mathrm{O}$ & & & - & - \\
\hline $1 "$ & - & 170,3153 & C- $\mathrm{O}_{2} \mathrm{H}$ & $1 "$ & - & $\begin{array}{r}10,3353 \\
(1 \mathbf{H}, s)\end{array}$ & $\mathrm{CO}_{2} \mathbf{H}$ \\
\hline $2 "$ & 70,7127 & 73,1351 & $\mathrm{OCH}_{2} \mathrm{CO}_{2}$ & $2 "$ & $\begin{array}{l}4,7344 \\
(2 \mathbf{H}, s)\end{array}$ & $\begin{array}{l}4,4776 \\
(2 \mathbf{H}, s)\end{array}$ & $\mathrm{CH}_{2} \mathrm{O}$ \\
\hline $1^{*}$ & 61,0646 & - & $\mathrm{CO}_{2} \mathrm{CH}_{2} \mathrm{CH}_{3}$ & $1^{*}$ & $\begin{array}{c}4,2045 \\
(2 \mathbf{H}, q, J= \\
6,7 \mathrm{~Hz})\end{array}$ & - & $\mathrm{OCH}_{\mathbf{2}} \mathrm{CH}_{3}$ \\
\hline $2 *$ & 14,4127 & - & $\mathrm{CO}_{2} \mathrm{CH}_{2} \mathrm{CH}_{3}$ & $2 *$ & $\begin{array}{c}1,2478 \\
(3 \mathbf{H}, t, J= \\
6,7 \mathrm{~Hz})\end{array}$ & - & $\mathrm{OCH}_{2} \mathrm{CH}_{3}$ \\
\hline
\end{tabular}


The ${ }^{13} \mathrm{C}$-NMR spectrum data of the BCAC4ND2 ionophore also strengthen the results of the FTIR and ${ }^{1} \mathrm{H}-\mathrm{NMR}$ spectrum analysis above. From the ${ }^{13} \mathrm{C}-\mathrm{NMR}$ spectrum data (Table 2) it appears that the BCAC4ND2 ionophore does not show any signal at $\delta_{\mathrm{C}} 61.0646 \mathrm{ppm}\left(\mathbf{C}-1^{*}\right)$ of methylene ethoxy carbon $\left(\mathrm{OCH}_{2} \mathrm{CH}_{3}\right)$, signal at $\delta_{\mathrm{C}} 14.4127 \mathrm{ppm}\left(\mathbf{C}-2^{*}\right)$ from methyl ethoxy carbon $\left(\mathrm{OCH}_{2} \mathrm{CH}_{3}\right)$, and the signal at $\delta_{\mathrm{C}} 169.6680 \mathrm{ppm}(\mathbf{C}-1$ ") from carbon carbonyl $(\mathbf{C}=\mathrm{O})$ esters. The presence of a signal at $\delta_{\mathrm{C}} 170.3153 \mathrm{ppm}$ (C-1") indicates that the BCAC4ND2 ionophore contains carbonyl carbon $(\mathbf{C}=\mathrm{O})$ carboxylic acid $\left(\mathbf{C}-\mathrm{O}_{2} \mathrm{H}\right)$. This shows that the hydrolysis reaction of the $p$ - $t$ butylcalix[4]arene ethylester forming the BCAC4ND2 ionophore has taken place.

The results of the ${ }^{13} \mathrm{C}-\mathrm{NMR}$ data analysis (Table 2) also provide a number of signals that fit into the BCAC4ND2 ionophore carbon framework. The signals of the aryl carbon atom (C-aryl) are scattered into four values of $\delta_{\mathrm{C}}$. First, the C-25 carbon atom shows the most downfield signal at $\delta_{\mathrm{C}} 146.8503 \mathrm{ppm}(\mathrm{CO}$ aryl) compared to the other aryl carbon because this $\mathbf{C}-25$ atom binds directly oxygen from the $\mathrm{OCH}_{2} \mathrm{CO}_{2} \mathrm{H}$ group. Second, the C-23 carbon absorption signal at $\delta_{\mathrm{C}} 144.5516 \mathrm{ppm}$ which binds to the tert-butyl group in the para (C-para aryl) position. Third, the $\mathbf{C}-1 / \mathbf{C}-21$ carbon absorption signal at the ortho position appears at $\delta_{\mathrm{C}} 127.8691 \mathrm{ppm}$ (C-ortho aryl). Fourth, the C-22/C-24 carbon absorption signal at the meta position appears at $\delta_{\mathrm{C}} 126.1236 \mathrm{ppm}$ (C-meta aryl). The more upfield carbon uptake groups are derived from alkyl groups. The methylene carbon $\left(\mathrm{OCH}_{2} \mathrm{CO}_{2} \mathrm{H}\right)$ absorption signal appears at $\delta_{C} 73.1351 \mathrm{ppm}$ (C-2"). The three strong absorption signals at $\delta_{\mathrm{C}}$ $34.1932,31.5892$, and $30.2348 \mathrm{ppm}$ were respectively derived from the carbon resonance quarterners of $t$-butyl $\left(\mathbf{C}-1^{\prime}\right)$, $\mathrm{CH}_{3}$ (C-2'), and $\mathrm{ArCH}_{2} \mathrm{Ar}$ (C-2/C-20). This sequence is based on the electronegativity effect of the atom bound by the carbon atom to the value of $\delta_{\mathrm{C}}$ and the relative intensity of the carbon absorption signal in the spectrum. Thus, the absorption that appears in the range of $\delta_{\mathrm{C}} 0-170 \mathrm{ppm}$ in the ${ }^{13} \mathrm{C}-\mathrm{NMR}$ spectrum of the synthesized product is in accordance with the carbon framework of 5,11,17,23tetracis(1,1-dimethylethyl)-25,26,27,28tetra(carboxymethoxy)calix[4]arene or the BCAC4ND2 ionophore (Figure 2). 


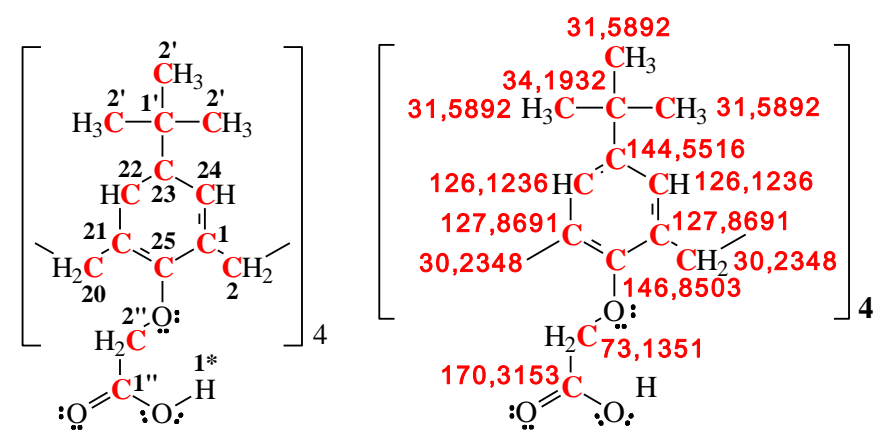

Figure 2. The position of the chemical shift value of ${ }^{13} \mathrm{C}-\mathrm{NMR}$ on the carbon framework of the BCAC4ND2 ionophore

The ${ }^{1} \mathrm{H}-\mathrm{NMR}$ spectrum of the BCAC4ND2 ionophore (Table 2) shows that the proton absorption band of the aryl group (ArH) appears as a singlet at $\delta_{\mathrm{H}}$ $7.0484 \mathrm{ppm}$, the methylene bridge proton absorption band $\left(\mathrm{ArCH} \mathrm{H}_{2} \mathrm{Ar}\right)$ appears as two doublets at $\delta_{\mathrm{H}} 4.2474 \mathrm{ppm}$ and 3.3939 ppm, and the $t$-butyl proton absorption band $\left[-\mathrm{C}\left(\mathrm{CH}_{3}\right)_{3}\right]$ appears as a singlet at $\delta_{\mathrm{H}}$ $1.2556 \mathrm{ppm}$. The pattern of these absorption bands indicates that the conformational form of the BCAC4ND2 ionophore is a cone (Figure 3) [15] [16]. The ${ }^{13} \mathrm{C}-\mathrm{NMR}$ spectrum of the BCAC4ND2 ionophore (Table 2) also strengthen that the conformational form of the BCAC4ND2 ionophore is cone (Figure 3). This can be seen by the presence of carbon absorption bands from the methylene bridge group $\left(\mathrm{ArCH}_{2} \mathrm{Ar}\right)$ that appear at $\delta_{\mathrm{C}} 30.2348 \mathrm{ppm}(\approx 31 \mathrm{ppm})$. This means that the orientation of two adjacent aryl groups is syn (a plot) with each other [17] [18].

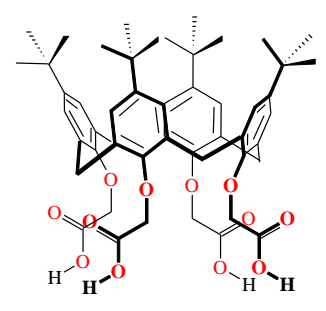

Figure 3. Cone conformation of the BCAC4ND2 ionophore

\section{Conclusion}

Synthesis of the BCAC4ND2 ionophore from $p$-t-butylcalix[4]arene ethylester as the raw material has been successfully carried through the reaction stage of base-promoted ester hydrolysis. 
Synthesis product was obtained as a white solid (62.38\% recovery), a melting point of 326-328 ${ }^{\circ} \mathrm{C}$, TLC $\left(\mathrm{SiO}_{2}\right.$, ethanol:ethyl acetate $\left.=1: 1 \mathrm{v} / \mathrm{v}, R_{\mathrm{f}}=0.93\right)$. The results of the synthesis product analysis with FTIR, ${ }^{1} \mathrm{H}$ and ${ }^{13} \mathrm{C}-\mathrm{NMR}$ spectrometers showed that the synthesis product is $5,11,17,23$ tetracis(1,1-dimethylethyl)-25,26,27,28tetra(carboxymethoxy)calix[4]arene or the BCAC4ND2 ionophore.

\section{Acknowledgements}

The authors would like to thank the staff of Integrated Laboratory Chemistry Department, Faculty of Mathematics and Natural Sciences University of Hasanuddin Makassar and Chemical Research Center of Indonesian Institute of Sciences for its assistance in analyzing the sample by FTIR, ${ }^{1} \mathrm{H}$ and ${ }^{13} \mathrm{C}-\mathrm{NMR}$ spectrometers.

\section{References}

[1] Sardjono, R., E. 2007. Sintesis dan Penggunaan Tetramer Siklis Seri Kaliksresorsinarena, Alkoksikaliksarena, dan Alkenilkaliksarena untuk Adsorpsi Kation Logam Berat. Universitas Gadjah Mada, Yogyakarta.

[2] Dali, N., Wahab, A. W., Firdaus, and Maming. 2012. Synthesis of 5,11,17,23,29,35-hexa(p-tert-butyl)37,39,41-tri(ethoxycarbonylmethoxy)- 38,40,42-tri(hydroxy)calix[6]arene from $\quad p$-tert-butylcalix[6]arene. Science Journal of Chemistry \& Chemical Education Vol. 1(2): 110115.

[3] Dali, N., Wahab, A. W., Firdaus, and Maming. 2015. Synthesis of 5,11,17,23-tetrakis( $p$-tert-butyl)25,26,27,28-tetrakis(ethoxycarbonylmethoxy)calix[4]arene from p-tertbutylcalix[4]arene. Dr. Aloei Saboe Vol. 1(2): 1-6.

[4] Arora, V., Chawla, H. M., and Singh, S. P. 2007. "Calixarenes as Sensor Materials for Recognition and Separation of Metal ions”. Arkivoc, (ii), 172-200.

[5] McKervey, M. A., Arrigan, D. W. M., Svehla, G., and Harris, S. J. 2016. Electroanalysis. 1994(6), 97-106. (Online). (http://www.arkausa.org/ark/journal/2013/McKervey/AM720R/ 720R.htm, accessed March 17, 2016).

[6] Kadir, A. N. 2014. Selectivity Transport Calixarene and Calixarene Carboxylic to $\mathrm{Fe}^{3+}$ of the Mixture $\mathrm{Fe}$, $\mathrm{Ni}$, and $\mathrm{Cr}$ Through the Bulk Liquid Membrane 1,2-dichloroethane. $\boldsymbol{d r}$. Aloei Saboe Vol. 1(2): 1-6.

[7] Kusumaningsih, T., Jumina, Siswanta, D., and Mustofa. 2010. Synthesis of Tetra- $p$-Propenyltetraestercalix[4]arene and Tetra- $p$-Propenyltetracarboxylicacidcalix[4]arene from $p$ - $t$ - 
Butylphenol. Indo. J. Chem. 10(1): 122-126.

[8] Dali, N., Wahab, A. W., Firdaus, and Maming. 2015. Synthesis hexa(p-tertbutyl)hexa(ester)calix[6] arene from $p$ tert-butylcalix[6]arene. Alchemy Science Research Journal of Chemistry Vol. 3(1): 103-109.

[9] Miller, I., Brown, D., and Schuh, M. 2002. Synthesis of Water Soluble Calixarene Carboxylate Salts and Spectroscopic Study of Their Inclusion Properties with Bromonaphtalene and Bromonaphthol. (Online). (http://www.chm.davidson.edu/projects/che 362/2002/ismiller, accessed May 19, 2015).

[10] Sherman, D. B., and Spatola, A. F. 1990. "Compatibility of Thioamides with Reverse Turn Features: Synthesis and Conformational Analysis of Two Model Cyclic Pseudopeptides Containing Thioamides as Backbone Modifications. J. Am. Chem. Soc. 112, 433-441.

[11] Maming, Jumina, Siswanta D., and Sastrohamidjojo, H. 2007. "Transport of $\mathrm{Cr}^{3+}, \mathrm{Cd}^{2+}, \mathrm{Pb}^{2+}$ and $\mathrm{Ag}^{+}$Ions Through Bulk Liquid Membrane Containing p-tertButylcalix[4]arene Tetracarboxylic
Acid as Ion Carrier". Indo. J. Chem. 7(1), 172-179.

[12] Lambert, J.B., Gronert, S., Shurvell, H.F., and Lightner, D.A. 2011. Organic Structural Spectroscopy. $2^{\text {nd }}$ Edition. Pearson Prentice Hall, New Jersey.

[13] Kemp, W. 1991. Organic Spectroscopy. $3^{\text {rd }}$ Ed. Macmillan Education Ltd., London.

[14] Sastrohamidjojo, H. 1992. Infrared Spectroscopy. $1^{\text {st }}$ Edition. Liberty, Yogyakarta.

[15] Arora, G. 2006. Calix[4]arenes with Proton-Ionizable Groups on the Lower and Upper Rim. A Thesis in Chemisatry. Graduate Faculty of Texas Tech University, Texas.

[16] Gutsche, C. D., Levine, J. A., and Sujeeth, P. K.. 1983. Calixarene. 17. Functionalized Calixarene: The Claisen Rearrangement Route. $\boldsymbol{J}$. Org. Chem. 50: 5802-5808.

[17] Gutsche, C. D., Dhawan, B., Hyun, N. K., and Muthocrishman, C. 1990. Calixarene. 4. The Synthesis, Caracterization, and Properties of Calixarenes from $p$ - $t$-Butylphenol. $\boldsymbol{J}$. Am. Chem. Soc. 103: 3782-3792.

[18] De Mendoza, J., Jaime, C., Prados, P., Nieto, P. M., and Sanchez, C. 1991. J. Org. Chem. 56, 3372. 